\title{
Wintertime Interactions of the Atmosphere with the Mediterranean Sea ${ }^{1,2}$
}

\author{
ANDREW F. BUNKER \\ Woods Hole Oceanographic Institution, Woods Hole, Mass. 02543 \\ (Manuscript received 17 December 1971, in revised form 3 March 1972)
}

\begin{abstract}
The net loss of heat by the Mediterranean Sea was determined for February 1969 while oceanographers observed the cooling and sinking of the water south of France. The heat loss during the four preceding months was found to be sufficient to produce the unstable stratification necessary for the sinking of the water. The mistral wind removed most of the heat through evaporation and sensible heat flux. On days when the mistral was blowing $1200 \mathrm{cal} \mathrm{cm}^{-2} \mathrm{day}^{-1}$ of heat and $1.5 \mathrm{~cm} \mathrm{day}{ }^{-1}$ of water were removed from the sea. Throughout the winter season an average of $400 \mathrm{cal} \mathrm{cm}^{-2} \mathrm{day}^{-1}$ was lost by the sea through sensible and latent heat fluxes. About half of the solar radiation absorbed by the water in the winter was lost through infrared radiation. Monthly heat exchanges are computed for an area south of France which show the dominant roles of latent heat exchange and solar radiation absorption in determining the temperature cycle and circulation of Mediterranean water.

The flow patterns, turbulence and energy exchange of the mistral wind have been studied through use of aircraft, ship, buoy and radiosonde observations. The maximum observed rms turbulent vertical velocities of the mistral wind was $204 \mathrm{~cm} \mathrm{sec}^{-1}$. The average shearing stress was $5 \mathrm{dyn} \mathrm{cm}^{-2}$. The evaporation from the sea was measured by an aircraft turbulence technique, accumulation along a trajectory, flux through the sides of a volume, and by an empirical formula. The formula gave an average evaporation rate which was closer to the overall average of all techniques than any other technique.
\end{abstract}

\section{Introduction}

\section{a. Interactions of the atmosphere and the Mediterranean Sea}

Interactions between the sea and air within the Mediterranean basin in conjunction with the irregular topography of the basin produce many distinctive flow patterns in both media. Evaporation lowers the level of the sea causing Atlantic water to flow into the Mediterranean Sea. The loss of heat and water vapor increases the density of the surface water until the water is unstable and sinks in preferred locations during the wintertime. This dense water flows out through the Strait of Gibraltar near the bottom beneath the inflowing, less dense Atlantic water. The complicated surface and sub-surface currents within the sea have been studied by Sverdrup (1942), Wüst (1952, 1961), Lacombe (1961) and others. During the winter of 1969 oceanographers studied in detail the changing currents and structure of the water in the western Mediterranean Sea south of the Rhone River, a region suspected of being a preferred location for the formation of dense water which would sink to the

${ }^{1}$ Contribution No. 2781 from the Woods Hole Oceanographic Institution. Research supported by the Atmospheric Sciences Section, National Science Foundation, under Grant GA-27218. The Office of Naval Research supported the field trip under Contract N00014-66-CO 241-13 NR 083-004.

2 Presented at the Conference on the Interaction of the Sea and the Atmosphere, 1-3 December 1971, Ft. Lauderdale, Fla. bottom of the Sea. The MEDOC Group (1970) reported the sinking of water near $42 \mathrm{~N}, 5 \mathrm{E}$ in mid February and many details concerning the processes involved.

The evaluation of the influence of the sea upon the atmosphere is greatly complicated by the presence of high mountains surrounding the sea and of mountainous islands within the sea. Because of the complex horizontal and vertical flow of air within the basin, many techniques have been employed to evaluate the heat flux, the evaporation, and the modification of the air flow due to the presence of the sea. Preliminary inspection of the data, both oceanographic and meteorological, showed that the greatest exchange of energy occurred during mistral wind occurrences. The mistral is a cold, dry wind that frequently blows down the Rhone Valley with great intensity and out over the waters of the western Mediterranean. The heat, water vapor and momentum fluxes associated with this wind are much greater than the fluxes resulting from air flows from other directions. Hence, the mistral wind and its interactions have been studied in greater detail than winds from other directions.

\section{b. Topography, air masses, precipitation and atmospheric circulations of the western Mediterranean basin}

The weather and climate over the western Mediterranean basin is influenced by five major features (terrain, west wind regime, subtropical high pressure 


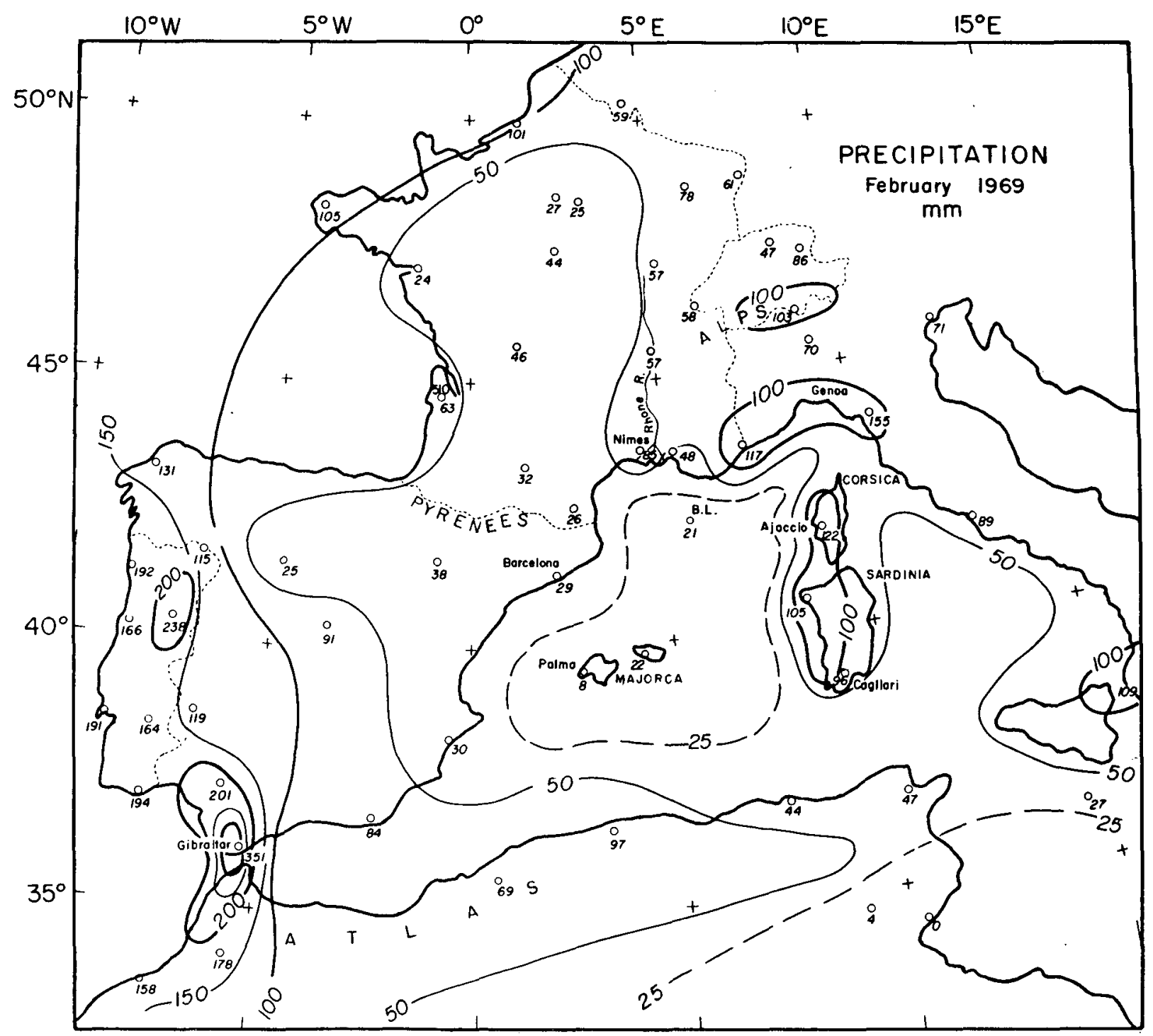

FIc. 1. Precipitation chart for February 1969, with amounts (m) being given below the observing station circle. The circle at $42^{\circ} 15^{\prime} \mathrm{N}, 5^{\circ} 30^{\prime} \mathrm{E}$ gives the location of the Bouée Laboratoire.

regime, west coast weather regime, and the water characteristics of the Mediterranean Sea) which interact in a complicated manner. The arrangement of the mountain ranges and mountainous islands produce distortions in the air flow with many scales of motion. The most significant of these flows for this study is the mistral wind which flows between the Alps and Pyrenees in the winter. The Alps also produce a cyclonic circulation of the air over the Gulf of Genoa. The Mediterranean basin is located near the boundary of the westerly winds and subtropical high-pressure cells. As the boundary wanders north or south, the weather in the basin is alternately characteristic of each of these regimes. When the high-pressure cell lies over Spain, upper air subsides over the basin. Since the Atlantic Ocean lies west of the mountain ranges, the weather has the characteristics of a west coast regime modified by mountains when the westerlies prevail. Finally, since the basin is filled with water, intense air-sea interactions occur particularly during the wintertime.

The predominant air mass occurring over the western basin in winter is a cold, dry continental air mass, unstable in the lower layers but stable aloft, generally designated cPks. The mistral winds usually are of this type but may be of arctic origin. Haurwitz and Austin (1944) give more details of Mediterranean air masses. Serra (1958) has made a study of the air masses arriving over Sardinia and their frequency of occurrence and relation to wind direction.

While the precipitation falling around the basin and on the Mediterranean islands is well known (Kendrew, 1942; Meteorological Office, 1964), the amounts falling 


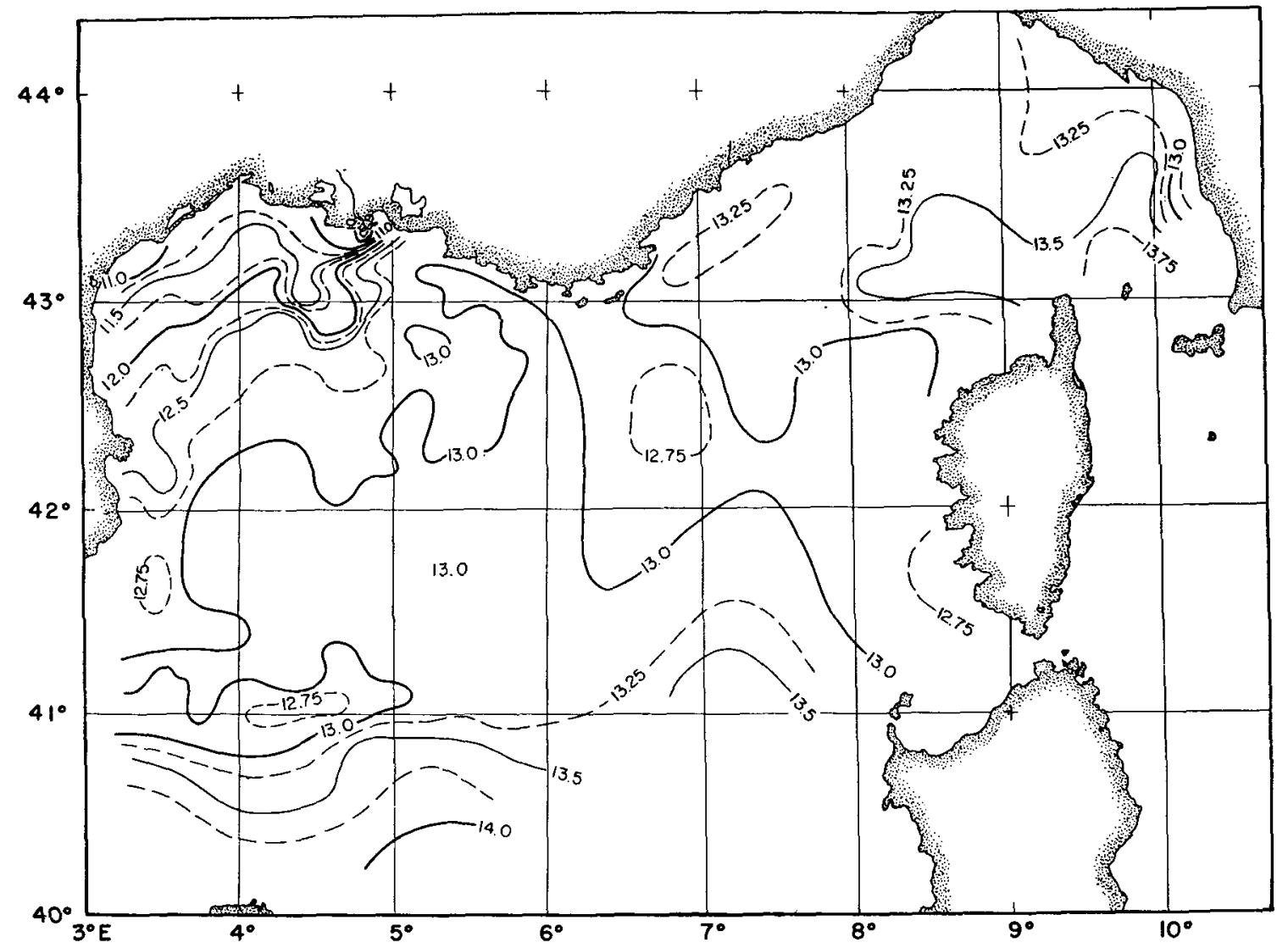

FIG. 2. Average sea surface temperatures $\left({ }^{\circ} \mathrm{C}\right)$ for all observational flights of the C-54Q aircraft during February 1969.

on the sea had to be estimated until measurements were made at $40^{\circ} 14^{\prime} \mathrm{N}, 5^{\circ} 30^{\prime} \mathrm{E}$ from the Bouée Laboratoire (BL). Rain frequencies are given by McDonald (1938) and the U. S. Naval Weather Service Command (1970) in the Summary of Synoptic Meteorological Observations (SSMO). From these sources an attempt was made to estimate the monthly rainfall over the western Mediterranean Sea. Fig. 1 presents the contoured precipitation for February 1969. It is seen that the rainfall over the sea is generally light except for the mountainous islands of Corsica and Sardinia where orographic effects predominate.

\section{c. Sources of data}

To obtain part of the data required to study the interactions, the $\mathrm{C}-54 \mathrm{Q}$ aircraft loaned to WHOI by the U. S. Navy through the Office of Naval Research was flown to the Mediterranean Sea. While stationed at the French Naval Air Station at Hyeres several flights were made over the western Mediterranean under different weather regimes. The aircraft was equipped with instruments to observe sea surface temperatures, air temperature and humidity, winds, short wavelength solar radiation, clouds, turbulent components of the wind, and the turbulent transport of heat, water vapor and momentum.
Synoptic surface and upper air observations obtained by meteorological stations around the Mediterranean and on islands have been used. Merchant ships and several research vessels working in the area supplied additional meteorological data. Solar radiation measurements were made on $\mathrm{R} / \mathrm{V}$ Allantis $I I$ on each day of February 1969. The $\mathrm{R} / \mathrm{V}$ Jean Charcot made radiosonde observations in the vicinity of $42 \mathrm{~N}, 5 \mathrm{E}$. The French Bouée Laboratoire (a manned, anchored buoy) made complete surface meteorological observations as well as oceanographical observations. Climatological data over the sea have been compiled by the U. S. Naval Weather Service Command (1970) in SSMO. These volumes give monthly means of winds, sea and air temperatures, and humidities for 33 areas within the Mediterranean Sea.

\section{d. Data collected during Aights of the C-54Q aircraft}

Flights were made over the western Mediterranean Sea on 13, 16, 18, 21, 24, 26 and 28 February 1969 to observe the atmospheric conditions during the final cooling stage and sinking of the surface water. From the data obtained charts were drawn showing 1) the surface weather over Spain, France, Italy, North Africa and the western Mediterranean Sea; 2) the winds, temperatures, mixing ratios, occurrences of 
precipitation, solar radiation, location of turbulence observations from the aircraft tracks (transparent overlays gave the cloud distribution observed during the flights); and 3) the observed sea surface temperatures. These charts are available in an unpublished manuscript by Bunker and Cornell (1971). The chart of the average sea surface temperature determined from the data obtained on all flights is presented in Fig. 2.

The turbulence equipment used aboard the C-54Q aircraft was developed earlier for use with other aircraft and has been-described by Bunker $(1955,1960)$. The system is essentially as described in the papers except that a better gyro and a microwave refractometer have been substituted. Reading of the records is accomplished by digitizing readers, and the computations are carried out by digital computer. The vertical component of the turbulent velocity is computed from

$$
w_{i}=a \Delta n / \rho V-b \Delta V / \rho V^{2}-V \Delta \alpha+\sum_{0}^{t_{i}} \Delta n \Delta t
$$

where $\Delta n$ is the vertical acceleration of the aircraft from a line of regression, $\Delta V$ a deviation of the indicated airspeed from its line of regression, and $\Delta \alpha$ the deviation of the measured attitude of the aircraft from its line of regression. Runs were $1 \mathrm{~min}$ long and measurements were made each fifth of a second. $V$ is the true air speed of the aircraft, $\rho$ the air density, and $\Delta t$ the measuring interval of $\frac{1}{5} \mathrm{sec}$. The constants $a$ and $b$ are values determined by the aerodynamic properties of the aircraft. Rapid fluctuations in temperature and humidity were measured by a fine platinum wire and the microwave refractometer. Fluxes of sensible heat, latent heat and momentum were found by forming the averages

$$
\begin{gathered}
H=c_{p} \rho \overline{w^{\prime} T^{\prime}}, \\
L E=L \overline{w^{\prime} q^{\prime}}, \\
\tau=-\rho \overline{w^{\prime} u^{\prime}},
\end{gathered}
$$

where primes represent the individual deviations of the velocity components, temperature and humidity; $c_{p}$ is the specific heat of air at constant pressure; and $L$ is the heat of condensation of water vapor.

The system does not respond to the full spectral range of turbulence but is limited to the wavelength range from about $15 \mathrm{~m}$ to $2 \frac{1}{2} \mathrm{~km}$. In the boundary layer at a height of $300 \mathrm{~m}$, about $75 \%$ of the turbulent vertical velocity energy will be contained within these limits according to graphs presented by Panofsky and McCormick (1960). A comparison of water vapor fluxes found by Fleagle et al. (1967) over the Arabian Sea with data obtained by the present equipment shows that the aircraft averaged $60 \%$ of the flux measured by the integral method and $75 \%$ of the value found by the profile method. Other limitations of the system will be discussed later in connection with particular parameters. Turbulence and flux data for all 78 runs and supplementary information are tabulated in Table 2 of Bunker and Comell.

\section{Flow patterns, stability, turbulence and stress over the western Mediterranean during periods of mistral winds}

\section{a. Flow patterns}

While the mistral is defined as a strong, cold dry wind blowing down the Rhone Valley, for the purposes of this study it is redefined in terms of the wind recorded at the Bouée Laboratoire. This floating laboratory was located about $125 \mathrm{~km}$ southeast of the mouth of the Rhone and reported winds six times daily. A mistral wind at this site was defined as any wind blowing from west to north with an average speed $\geqslant 25 \mathrm{kt}$. Applying this definition 12 days qualified as mistral days during February 1969. The mistral blew from $326^{\circ}$ with an average speed of $17.1 \mathrm{~m} \mathrm{sec}^{-1}$. On the non-mistral days the average wind speed was 8.0 $\mathrm{m} \mathrm{sec}^{-1}$ while the resultant wind was $1.5 \mathrm{~m} \mathrm{sec}^{-1}$ from $181^{\circ}$.

The flow patterns over the western Mediterranean associated with the mistral have been determined using ship observations. Two preferred circulation patterns are noted. One pattern, observed on $6,15,16,24,25$ February 1969, is characterized by a broad band of west winds with slight cyclonic curvature over all parts of the western Mediterranean. The other preferred pattern is shown in Fig. 3, a composite flow diagram built up from winds observed on $8,9,10,11$ and 26 February 1969. This flow is characterized by northeast winds in the southeast part of the western basin and northwest winds in the southwest part. The separation of the flow into two streams occurs off the North African coast at about $7 \mathrm{E}$. The flow pattern on 4 and 5 February 1969 was similar but the separation off Africa occurs farther west at $1 \mathrm{E}$. The northeasterly winds are associated with a ridge of high pressure extending over Spain from a North Atlantic highpressure center located northwest of Spain. Over the Gulf of Genoa a cyclonic circulation is observed.

This latter flow is associated with anomalously low humidities observed at Cagliari on Sardinia. On 8 February a relative humidity of only $10 \%$ was recorded at $925 \mathrm{mb}$. Such low humidities must result from the subsidence caused by the divergence of the wind off the coast of Africa augmented by local effects of the mountains of Sardinia. A plot of temperatures and dew points for Nimes, R/V Jean Charcol, and Cagliari on 9 February (Fig. 4) shows the progressive development of a subsidence inversion and the dry air over Cagliari.

\section{b. Stability and turbulence}

The observations obtained on 16 February, a day with a well-developed mistral wind, are sufficient to 


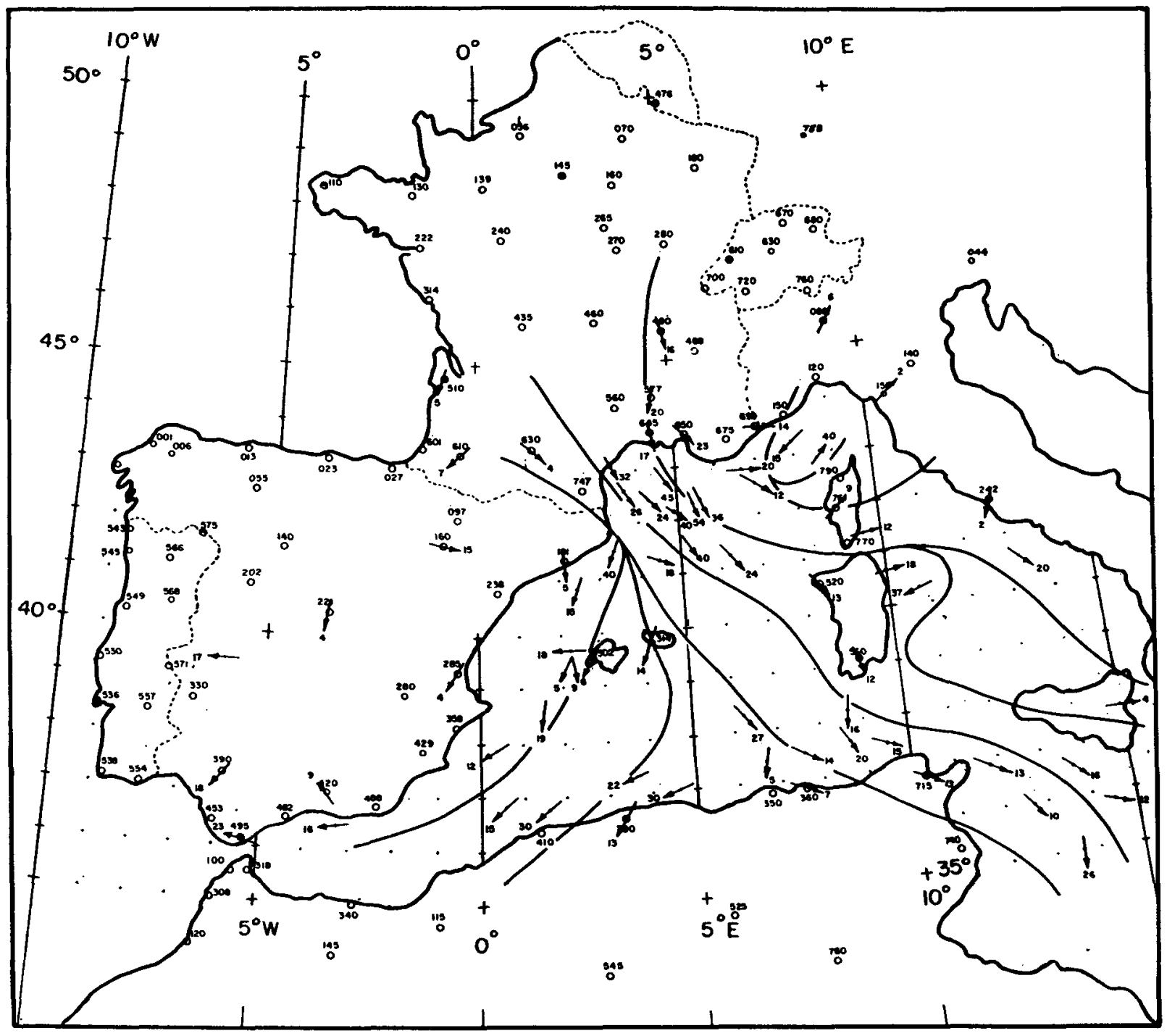

Fig. 3. Mistral wind flow pattern associated with Atlantic high pressure ridge extending into Spain.

study the distribution of the turbulence, stability and wind strength of a strong mistral. The air as it passed over Nimes had a temperature of $1 \mathrm{C}$ and a velocity of about $10 \mathrm{~m} \mathrm{sec}^{-1}$. The water near the shore had a temperature of $11 \mathrm{C}$, thus heating the air from below and producing instability. At BL the air temperature was $4.6 \mathrm{C}$, the sea temperature $12.8 \mathrm{C}$, and the wind $18 \mathrm{~m} \mathrm{sec}^{-1}$. A sounding to $1000 \mathrm{~m}$ was made by the C-54Q aircraft at $41 \mathrm{~N}, 6 \mathrm{E}$, which shows the instability and turbulence $300 \mathrm{~km}$ downwind from the coast line. The average wind from 200 to $1000 \mathrm{~m}$ was $14 \mathrm{~m} \mathrm{sec}^{-1}$. The potential temperature and turbulence parameters are plotted against height in Fig. 5. The temperature curve shows that the air is unstable to $600 \mathrm{~m}$ and stable above that level. In the area there was $4 / 8$ sky coverage by cumulus clouds with bases at $850 \mathrm{~m}$. The plot shows an increase in turbulence with height in the lower unstable layer and a decrease in the stable layer.
The outstanding feature of mistral wind turbulence is that the turbulence is greater than that of any air mass yet measured with the present equipment, exclusive of cumulus cloud penetrations. An rms vertical component of the turbulent velocity, $\sigma_{w}$, of $204 \mathrm{~cm} \mathrm{sec}^{-1}$ was measured at $400 \mathrm{~m}$ about $50 \mathrm{~km}$ off the mouth of the Rhone River. The average of all values of $\sigma_{w}$ below $400 \mathrm{~m}$ was $154 \mathrm{~cm} \mathrm{sec}^{-1}$ while the average rms horizontal component, $\sigma_{u}$, was $151 \mathrm{~cm} \mathrm{sec}^{-1}$. The turbulence decreased slowly toward the south so that $300 \mathrm{~km}$ offshore the average $\sigma_{w}$ was $130 \mathrm{~cm} \mathrm{sec}^{-1}$. For comparison, the previous maximum value reported by Bunker (1960) was $177 \mathrm{~cm} \mathrm{sec}^{-1}$ observed over the Gulf Stream on 18 January 1955 during an outbreak of cold air over the North Atlantic. The average $\sigma_{w}$ for all cold outbreaks studied over the Atlantic measured between 100 and $600 \mathrm{~m}$, or the base of the stable layer, was $100 \mathrm{~cm} \mathrm{sec}^{-1}$. 


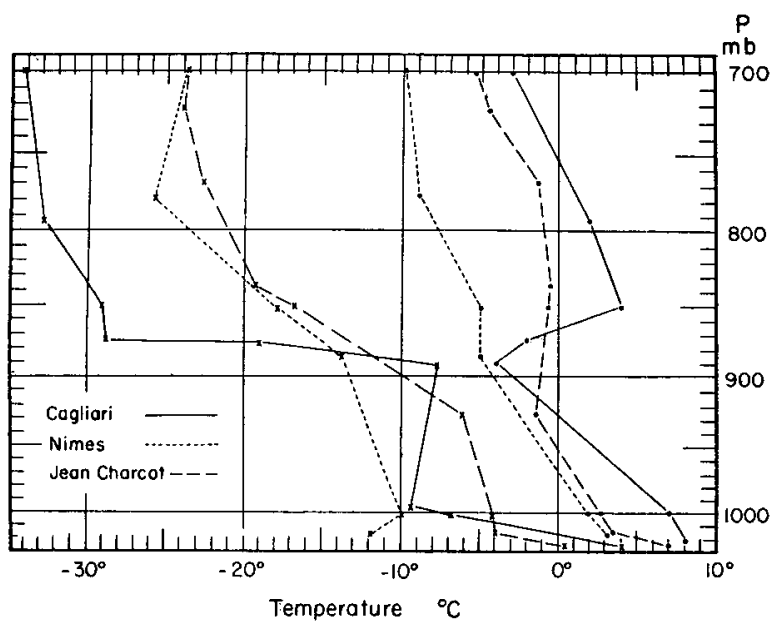

Fig. 4. Temperature and dew points observed by radiosonde ascents made at 1200 GMT 9 February 1969 at Nimes, France, $\mathrm{R} / \mathrm{V}$ Jean Charcot at $42^{\circ} 11^{\prime} \mathrm{N}, 04^{\circ} 58^{\prime} \mathrm{E}$, and Cagliari, Sardinia.

\section{c. Reynolds stresses of the mistral aind}

The individual measurements of stress may be expressed as

$$
\left(-\rho \overline{w^{\prime} u^{\prime}}\right)_{m}=\tau_{a} \cos \theta+\epsilon,
$$

where $\theta$ is the angle between the heading of the aircraft and the wind, $\epsilon$ an error caused by instrumental correlations between $w^{\prime}$ and $u^{\prime}$, and $\tau_{a}$ the stress of the wind in the downwind direction at flight altitude.

The individual values of stress, wind speed, and aircraft heading have been processed to eliminate the effect of the aircraft heading relative to the wind, to eliminate the instrumental errors, to average the stresses, and to determine the drag coefficient $C_{D}$ from

$$
\tau=c_{D} \rho V^{2} \text {. }
$$

All stresses were separated into three groups according

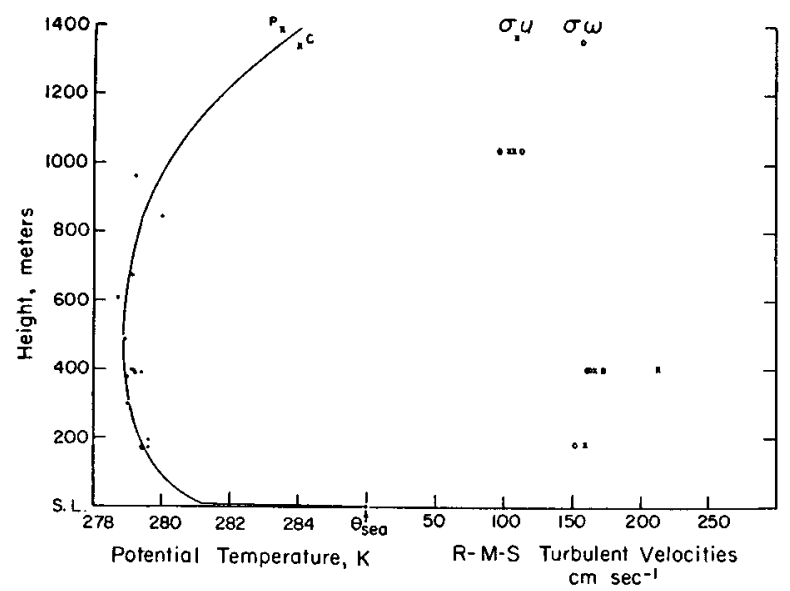

FrG. 5. Turbulent velocities and potential temperatures observed near 41N, 6E by the C-54Q aircraft on 16 February 1969. Crosses marked $\mathrm{P}$ and $\mathrm{C}$ give potential temperatures at Palma and Cagliari. to wind speed, i.e., low speed, $1.9-7.9 \mathrm{~m} \mathrm{sec}^{-1}$; medium speed, $8.0-12.9 \mathrm{~m} \mathrm{sec}^{-1}$; and high speed, $13.0-18.2 \mathrm{~m}$ $\mathrm{sec}^{-1}$. The stresses for each speed group were then separated into four sectors, $300^{\circ}-60^{\circ}, 60^{\circ}-120^{\circ}, 120^{\circ}$ $240^{\circ}$ and $240^{\circ}-300^{\circ}$, according to wind direction relative to the heading of the aircraft. Averages of the stress for each sector were formed. The unweighted average of the four sectors were then formed. This represents the systematic instrumental error, $\epsilon$, since the stress averaged over all relative wind directions should be zero. This average was subtracted from the average of the upwind and downwind sectors. The sign of the value for the downwind sector was reversed and the weighted average of the two sectors found. These averages were divided by $\cos \theta$ averaged from $300^{\circ}-60^{\circ}$. These quotients were considered to be the best values of the stress of the wind in the downwind direction for each wind speed group. The average stress, $\overline{\tau_{a}}$, for each speed group was found to be 0.44 , 1.16 and 5.15 dyn $\mathrm{cm}^{-2}$. These average stresses have been plotted in Fig. 6 against the average square of the wind speed. Lines of three values of $C_{D}$ according to Eq. (7) have been entered on the diagram. It appears that $C_{D} \approx 1.5 \times 10^{-3}$ fits the plotted points fairly well. It should be noted that the stress was measured at $400 \mathrm{~m}$ and the surface stress should be greater. If the stress decreases linearly with height and zero stress occurs at $2000 \mathrm{~m}$, then the surface stress of the mistral wind should average about $6.4 \mathrm{dyn} \mathrm{cm}^{-2}$.

One might expect to find that large stresses persisting for several days produce prominent surface currents in the sea. However, currents were monitored at $\mathrm{BL}$ and during February the surface currents fluctuated in the vicinity of $10 \mathrm{~cm} \mathrm{sec}$. The reason for this apparent paradox is that the water had become neutrally stable all the way to the bottom and the momentum gained from the atmosphere was mixed throughout the $2500 \mathrm{~m}$ water column. A stress of 6 dyn $\mathrm{cm}^{-2}$ acting on such a water column situated at $45 \mathrm{~N}$ on the rotating earth

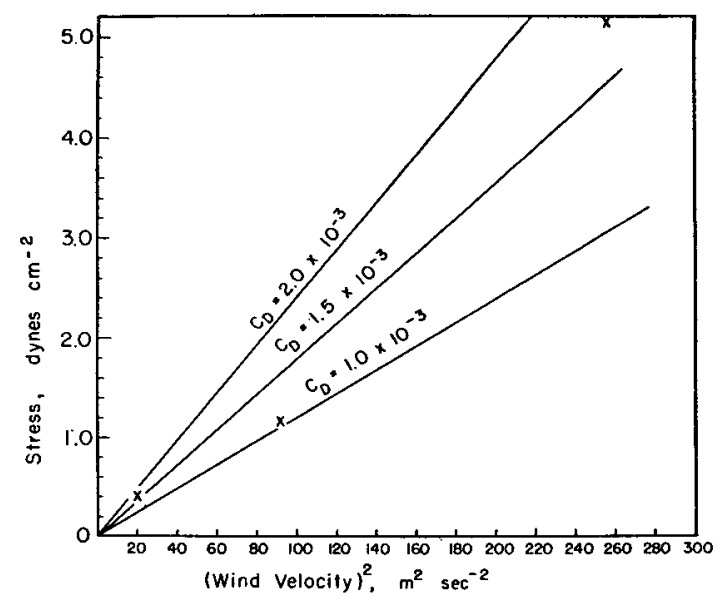

FIG. 6. Mean stresses observed during February 1969 by the $\mathrm{C}-54 \mathrm{Q}$ aircraft vs the square of the wind velocity. 
would produce an oscillating current of only a few tenths of a centimeter per second.

\section{Computation of evaporation}

Because of the important role that evaporation plays in the circulation of the Mediterranean water and the modification of the air, four techniques have been employed to obtain a meaningful value of the evaporation rate. These four are: 1) the turbulent transport techuique involving the measurement of turbulent velocities $w^{\prime}$ and humidity fluctuations $q^{\prime}$ from an aircraft; 2) the technique of measuring the accumulation of water vapor in the air along air trajectories; 3) the technique of measuring the flow of water vapor into and out of a volume of air over the water; and 4) the bulk aerodynamic technique utilizing the wind speed, humidity, sea temperature, and an empirical parameter which may be constant or may vary with the wind speed and stability. The major difficulty with each of these four techniques is as follows: 1) the turbulence runs were short and limited to the small range of gusts that can be measured, and instrumental errors may be significant; 2) the trajectory and airspeed over water is not known accurately; 3) local effects of the terrain force unrepresentative values of the winds and humidities; and 4) an exact value for the empirical parameter in the evaporation formula is not known. At the end of this section the evaporation determined by the four methods are compared.

\section{a. Turbulent transport of water vapor}

The turbulent transport of water vapor was measured by the aircraft technique on three days classified as mistral wind days- $-16,24$ and 26 February 1969. The average fluxes through the flight level for each day are listed in the following table. The accumulation rate refers to the rate at which water vapor accumulates in the layer of air from the surface to the flight level of the aircraft. This rate was found from the change in the amount of water vapor in the layer from the coast line to the most distant point, divided by the transit time of the air mass. The surface flux of water vapor is the sum of the flux through the flight level plus the accumulation rate below the aircraft. The average
TABLE 1. Turbulent transport of water vapor $\left(\mathrm{gm} \mathrm{cm}^{-2} \mathrm{day}^{-1}\right)$ during the mistral winds.

\begin{tabular}{ccccc}
$\begin{array}{c}\text { Date } \\
\text { (February) }\end{array}$ & $\begin{array}{c}\text { Flight } \\
\text { level } \\
(\mathrm{m})\end{array}$ & Flux & $\begin{array}{c}\text { Accumula- } \\
\text { tion } \\
\text { rate }\end{array}$ & $\begin{array}{c}\text { Surface } \\
\text { flux }\end{array}$ \\
\hline 16 & 400 & 0.58 & 0.38 & 0.96 \\
24 & 275 & 0.14 & 0.05 & 0.19 \\
26 & 300 & 0.33 & 0.09 & 0.42 \\
\hline
\end{tabular}

evaporation during mistral wind regimes from Table 1 is $0.52 \mathrm{gm} \mathrm{cm}^{-2}$ day ${ }^{-1}$. However, as pointed out earlier, the aircraft technique underestimates the flux of water vapor by about $40 \%$. If a correction is applied to the flux in column 3 to eliminate this failing, then an average of $0.76 \mathrm{gm} \mathrm{cm}^{-2} \mathrm{day}^{-1}$ is found.

The average of the water vapor fluxes obtained on all days is $0.27 \mathrm{gm} \mathrm{cm}^{-2} \mathrm{day}^{-1}$. Correcting this value for underestimation of the system and adding the estimated accumulated water vapor below flight level gives an average surface evaporation of $0.58 \mathrm{gm} \mathrm{cm}^{-2}$ $\mathrm{day}^{-1}$.

\section{b. Evaporation determinations from accumulation along air trajectories}

Another method of determining the evaporation from the sea is available if radiosonde observations have been made along an air trajectory. In the present case, $\mathrm{R} / \mathrm{V}$ Jean Charcot made radiosonde observations in the area downwind of the Nimes rawin station. Using these observations, together with the surface wind at BL and Charcot, the evaporation on six mistral wind days has been computed and is presented in Table 2. Table 5 gives the evaporation found on other days. Given here are the mean mixing ratios from the surface to $700 \mathrm{mb}$ at Nimes and $\mathrm{R} / \mathrm{V}$ Jean Charcot, the difference in precipitable water $(\triangle P W)$, the distance of the Charcot from the coast line, the mean wind speed, the time required for the air to travel from the coast to the Charcot, and the amount of water evaporated into the air less any loss by precipitation $(E-P)$. The last two columns give the values of the precipitation as measured at $\mathrm{BL}$, and the evaporation. $\mathrm{A}$ mean evaporation of $2.7 \mathrm{gm} \mathrm{cm}^{-2} \mathrm{day}^{-1}$ is found.

On six mistral days with no missing data, the air that passed over Nimes also passed over or close to

TABLE 2. Evaporation rates along a trajectory between Nimes and R/V Charcot on mistral days.

\begin{tabular}{|c|c|c|c|c|c|c|c|c|c|}
\hline $\begin{array}{c}\text { Date } \\
\text { (February) }\end{array}$ & $\begin{array}{l}\text { Mixin } \\
\text { (gm } \\
\text { Nimes }\end{array}$ & $\begin{array}{l}\text { ratios } \\
\left.\mathrm{kg}^{-1}\right) \\
\text { Charcot }\end{array}$ & $\begin{array}{c}\Delta P W \\
\left(\mathrm{gm} \mathrm{cm}^{-2}\right)\end{array}$ & $\begin{array}{l}\text { Distance } \\
(\mathrm{km})\end{array}$ & $\underset{\left(m \operatorname{mec}^{-1}\right)}{\text { Wind }}$ & $\begin{array}{l}\text { Transit time } \\
\quad\left(\sec \times 10^{4}\right)\end{array}$ & $E-P$ & $\begin{array}{c}P \\
\mathrm{~m}^{-2}\end{array}$ & $E$ \\
\hline 4 & 1.3 & 3.2 & 0.57 & 170 & 13.4 & 12.7 & 4.49 & 0.2 & 4.69 \\
\hline 5 & 1.1 & 2.0 & 0.27 & 155 & 15.3 & 10.1 & 2.33 & 0.0 & 2.33 \\
\hline 6 & 1.3 & 2.2 & 0.27 & 155 & 11.2 & 10.4 & 2.60 & 0.0 & 2.60 \\
\hline 8 & 1.1 & 2.6 & 0.39 & 192 & 11.0 & 17.5 & 2.23 & 0.0 & 2.23 \\
\hline 9 & 1.2 & 1.6 & 0.12 & 165 & 14.5 & 11.4 & 1.05 & 0.0 & 1.05 \\
\hline 10 & 0.9 & 1.6 & 0.27 & 135 & 15.8 & 8.5 & 3.18 & 0.0 & 3.18 \\
\hline Average & & & & & & & & & 2.68 \\
\hline
\end{tabular}


TABLE 3. Evaporation rates along a trajectory between Nimes and Ajaccio on mistral days.

\begin{tabular}{|c|c|c|c|c|c|c|c|c|c|}
\hline$\frac{\begin{array}{c}\text { Date } \\
\text { (February) }\end{array}}{8}$ & \multicolumn{2}{|c|}{$\begin{array}{l}\text { Mixing ratios } \\
\left(\mathrm{gm} \mathrm{kg} \mathrm{kg}^{-1}\right)\end{array}$} & $\frac{\begin{array}{c}\Delta P W \\
\left(\mathrm{gm} \mathrm{cm}^{-2}\right)\end{array}}{0.54}$ & $\begin{array}{c}\begin{array}{c}\text { Distance } \\
(\mathrm{km})\end{array} \\
360\end{array}$ & $\begin{array}{l}\text { Wind } \\
\left(\mathrm{m} \sec ^{-1}\right)\end{array}$ & $\begin{array}{c}\text { Transit time } \\
\left(\sec \times 10^{4}\right)\end{array}$ & \multicolumn{2}{|c|}{$\underset{\left(\mathrm{gm} \mathrm{cm}^{-2} \mathrm{day}^{-1}\right)}{E-P} \stackrel{P}{P}$} & $E$ \\
\hline $\begin{array}{r}8 \\
15 \\
16 \\
24 \\
25 \\
26\end{array}$ & $\begin{array}{l}0.76 \\
1.82 \\
0.46 \\
2.74 \\
2.38 \\
2.04\end{array}$ & $\begin{array}{l}1.84 \\
2.86 \\
1.64 \\
3.28 \\
2.78 \\
2.64\end{array}$ & $\begin{array}{l}0.54 \\
0.52 \\
0.59 \\
0.27 \\
0.20 \\
0.30\end{array}$ & $\begin{array}{l}360 \\
360 \\
360 \\
360 \\
360 \\
360\end{array}$ & $\begin{array}{r}18.8 \\
14.5 \\
15.5 \\
8.8 \\
6.6 \\
8.6\end{array}$ & $\begin{array}{l}1.9 \\
2.5 \\
2.3 \\
4.1 \\
5.5 \\
4.2\end{array}$ & $\begin{array}{l}2.45 \\
1.80 \\
2.22 \\
0.57 \\
0.31 \\
0.61\end{array}$ & $\begin{array}{l}0.0 \\
1.0 \\
1.0 \\
0.0 \\
0.0 \\
1.0\end{array}$ & $\begin{array}{l}2.45 \\
2.80 \\
3.22 \\
0.57 \\
0.31 \\
1.61\end{array}$ \\
\hline Average & & & & & & & & & 1.82 \\
\hline
\end{tabular}

Ajaccio. To determine the evaporation minus precipitation, averages of the mixing ratios and winds from the surface to $500 \mathrm{mb}$ were found. The difference between the water contents in the air columns over Nimes and Ajaccio was found and divided by the transit times between the two stations. An $E-P$ value of $1.3 \mathrm{gm} \mathrm{cm}^{-2} \mathrm{day}^{-1}$ was found. No rainfall was reported at BL, but shower-type rain was reported at Ajaccio on three of the six days. No rainfall amounts are available. If $10 \mathrm{~mm}$ of rain fell on each of three days, then evaporation would amount to $1.8 \mathrm{gm} \mathrm{cm}^{-2}$ day $^{-1}$. Table 3 presents the individual terms.

\section{c. Computations of $E-P$ from mass and water vapor flow through volumes}

A program was written to compute the mass flow and water vapor flow into and out of volumes above areas defined by three rawin observing stations, using equations adapted from the works of Benton and Estoque (1954) and Starr and Peixoto (1958). From the convergence or divergence of the mass, the vertical velocities were computed at the $850-, 700-, 500$ - and $300-\mathrm{mb}$ levels. Two triangular areas were considered for the computations: 1) Nimes, Palma and Ajaccio, and 2) Ajaccio, Palma and Cagliari.

The terrain of the Mediterranean basin and the nature of the mistral winds were found to produce winds and humidities at observing stations which are unrepresentative of the general area. To obtain values of the wind which were more representative, ship observations and Bouée Laboratoire surface winds were used in preference to the surface winds at the land and island weather stations. The $850-\mathrm{mb}$ winds from the rawin stations were accepted as representative of the layer from 950 to $850 \mathrm{mb}$ and average winds along the sides were found. Above $850 \mathrm{mb}$ simple averages were formed for the various layers from the rawin reports. The representativeness of the 850 - and $700-\mathrm{mb}$ winds at Ajaccio and Cagliari is questionable since mountain peaks on Corsica and Sardinia rise to 720 and $820 \mathrm{mb}$, respectively. The mixing ratios may be more representative of the general area, but subsidence in the Mannu Valley in which the Cagliari station is located may cause depressed values of the water vapor content. As a result of this local anomaly many computed evaporations were negative for the Ajaccio-Palma-Cagliari triangle. None of the values for this triangle are presented here or considered further. At Ajaccio upslope winds may increase the mixing ratio at the higher levels.

The equations used for determining the fluxes assume that nearly steady-state wind and moisture conditions prevail over the area. After eliminating days with obviously unsteady conditions and days with missing data, 11 days in February 1969 were available for computation. Of these, seven were mistral days, two days had weak west winds, one day had a steady south

TABLE 4. Evaporation and vertical velocities for the Nimes-Palma-Ajaccio triangle.

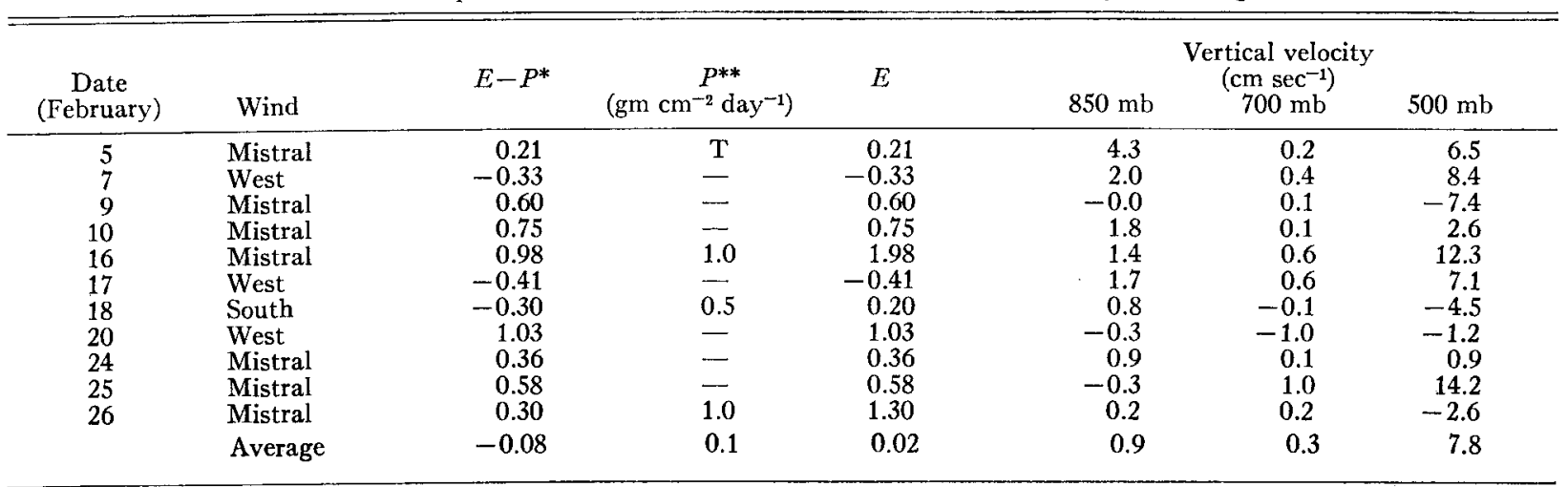

* Surface to $700 \mathrm{mb}$.

** Estimated. 
Table 5. Summary of evaporation determinations $\left(\mathrm{gm} \mathrm{cm}^{-2} \mathrm{day}^{-1}\right)$ from the French Coast to 40N, February 1969.

\begin{tabular}{|c|c|c|c|c|c|c|c|c|c|c|}
\hline \multirow[b]{2}{*}{ Date } & \multirow[b]{2}{*}{$\begin{array}{l}\text { Wind } \\
\text { pattern }\end{array}$} & \multirow{2}{*}{$\begin{array}{l}\text { Turbulent } \\
\text { transport } \\
\text { method }\end{array}$} & \multirow{2}{*}{$\begin{array}{c}\text { Trajectory } \\
\text { Nimes to } \\
\text { Jean } \\
\text { Charcot }\end{array}$} & \multirow{2}{*}{$\begin{array}{l}\text { method } \\
\text { Nimes to } \\
\text { A jaccio }\end{array}$} & \multirow{2}{*}{$\begin{array}{l}\text { Volume flux } \\
\text { method } \\
\text { (Nimes-- } \\
\text { Palma-Ajaccio } \\
\text { triangle) }\end{array}$} & \multicolumn{5}{|c|}{$\begin{array}{l}\text { Evaporation formula } \\
\qquad \mathrm{R} / \mathrm{V}\end{array}$} \\
\hline & & & & & & BL & Ships & $\begin{array}{l}\text { Jean } \\
\text { Charcot }\end{array}$ & Allantis & $\begin{array}{l}\text { Daily } \\
\text { average }\end{array}$ \\
\hline 1 & NW & & 0.95 & & & 0.22 & 0.26 & & 0.14 & 0.39 \\
\hline 2 & SW & & & & & 0.35 & 0.16 & 0.05 & 0.33 & 0.22 \\
\hline 3 & NW Fro & & 1.38 & 0.60 & & 0.37 & & 0.23 & 0.40 & 0.60 \\
\hline 4 & Mistral & & 4.69 & & & 1.40 & & 0.94 & & 2.34 \\
\hline 5 & Mistral & & 2.33 & & 0.21 & 1.68 & & & 1.22 & 1.36 \\
\hline 6 & Mistral & & 2.60 & & & 1.58 & & 1.40 & & 1.86 \\
\hline 7 & $\mathrm{~W}$ & & & & -0.33 & 0.54 & & 0.77 & 0.15 & 0.28 \\
\hline 8 & Mistral & & 2.23 & 2.45 & & 1.63 & & & & 2.10 \\
\hline 9 & Mistral & & 1.05 & & 0.60 & 2.30 & & & & 1.32 \\
\hline 10 & Mistral & & 3.18 & & 0.75 & 2.15 & 1.46 & 2.13 & 2.04 & 2.03 \\
\hline 11 & Mistral & & & & & 1.99 & & 2.15 & & 1.99 \\
\hline 12 & SW & & & & & 0.80 & & & & 0.80 \\
\hline 13 & Front & 0.33 & & & & 0.23 & 0.32 & & & 0.27 \\
\hline 14 & $\mathrm{NE}$ & & & & & 0.32 & 0.12 & & & 0.22 \\
\hline 15 & Mistral & & & 2.80 & & 1.40 & 0.99 & 1.65 & & 1.71 \\
\hline 16 & Mistral & 1.35 & & 3.22 & 1.98 & 1.99 & 0.77 & 2.57 & & 1.98 \\
\hline 17 & NW & & 0.43 & & -0.41 & 1.15 & & 1.15 & 0.33 & 0.53 \\
\hline 18 & $\mathrm{~S}$ & & & & 0.20 & 0.50 & 1.43 & 0.58 & 0.49 & 0.64 \\
\hline 19 & SE & & & & & 0.15 & & 0.08 & 0.22 & 0.15 \\
\hline 20 & W & & 1.21 & & 1.03 & 0.09 & & 0.18 & 0.08 & 0.52 \\
\hline 21 & SW & 0.30 & & & & 0.48 & & 0.35 & 0.05 & 0.30 \\
\hline 22 & Frontal & & & & & 0.30 & & 0.31 & 0.23 & 0.28 \\
\hline 23 & Frontal & & (2.94) & & & 0.15 & & 0.25 & 0.10 & 0.86 \\
\hline 24 & Mistral & 0.28 & & 0.57 & 0.36 & 0.53 & & 1.08 & 0.31 & 0.52 \\
\hline 25 & Mistral & & & 0.31 & 0.58 & 0.69 & & 1.03 & 0.63 & 0.65 \\
\hline 26 & Mistral & 0.64 & & 1.61 & 1.30 & 0.79 & & 0.30 & 0.86 & 0.92 \\
\hline 27 & & & & & & 0.30 & 0.31 & & 0.08 & 0.23 \\
\hline 28 & $\mathrm{E}$ & & & & & 0.57 & 0.29 & & 0.47 & 0.44 \\
\hline \multicolumn{2}{|c|}{ Average } & 0.58 & 2.09 & 1.65 & 0.57 & 0.88 & 0.61 & 0.91 & 0.45 & 0.91 \\
\hline \multicolumn{2}{|c|}{$\begin{array}{l}\text { BL average for } \\
\text { same dates }\end{array}$} & 0.80 & 1.16 & 1.06 & 1.13 & & 0.80 & 0.87 & 0.61 & 0.88 \\
\hline \multicolumn{2}{|c|}{$\begin{array}{l}\text { Percent of } \mathrm{BL} \\
\text { average }\end{array}$} & 73 & 180 & 156 & 50 & & 76 & 105 & 74 & 103 \\
\hline
\end{tabular}

wind, and a cold front passed over the area on the 20th. The computations were also carried out for the average winds and humidities for the month of February 1969. The computed evaporations and vertical velocities for the Nimes-Palma-Ajaccio triangle are presented in Table 4.

\section{d. Evaporation determined from surface observalions and comparison of techniques}

Sverdrup (1937) and Montgomery (1940) have developed theoretical evaporation equations of the form

$$
E=\rho K\left(q_{w}-q_{a}\right) W,
$$

in which $\rho$ is the air density, $q_{w}$ the saturation mixing ratio of the air in contact with the sea surface, $q_{a}$ the mixing ratio of the air at height $a$, and $W$ the wind at anemometer level. The factor $K$ depends upon the product of the diffusion coefficient and wind gradient in Sverdrup's development and the product of the resistance and evaporation coefficients in Mongomery's development. The factor, now usually identified as the drag coefficient $C_{D}$, was found to be nearly invariant with the surface roughness. In order to compute evaporation over the oceans using Eq. (7) with climatological averages of the meteorological and oceanographical parameters, Jacobs (1942) and Budyko (1963) determined the factor $C_{D}$ empirically. This was done by determining the value of $C_{D}$ which balanced the energy budget of the oceans. Jacobs found a value of $2.3 \times 10^{-3}$ and Budyko $2.1 \times 10^{-3}$. The accuracy of the energy balance is not known. Other workers (Laevastu, 1965; Garstang, 1965; $\mathrm{Wu}, 1969)$ have investigated the variation of $C_{D}$ with stability and wind speed and have developed various expressions for its variation. Since Budyko has published evaporation charts for all oceans, his value of $C_{D}$ has been used for the computation of evaporation from climatological data obtained over the Mediterranean Sea. The computed evaporations therefore should be comparable with Budyko's evaporation values.

To determine evaporation from single observations or daily averages of wind and humidity differences a value of $C_{D}$ equal to $1.9 \times 10^{-3}$ was used. This smaller value was used since the monthly average of the daily evaporation was $10 \%$ higher than the monthly average determined from the monthly mean of the wind and humidity differences. The following equations were used to compute evaporation $\left(\mathrm{gm} \mathrm{cm}{ }^{-2} \mathrm{day}^{-1}\right)$ from 


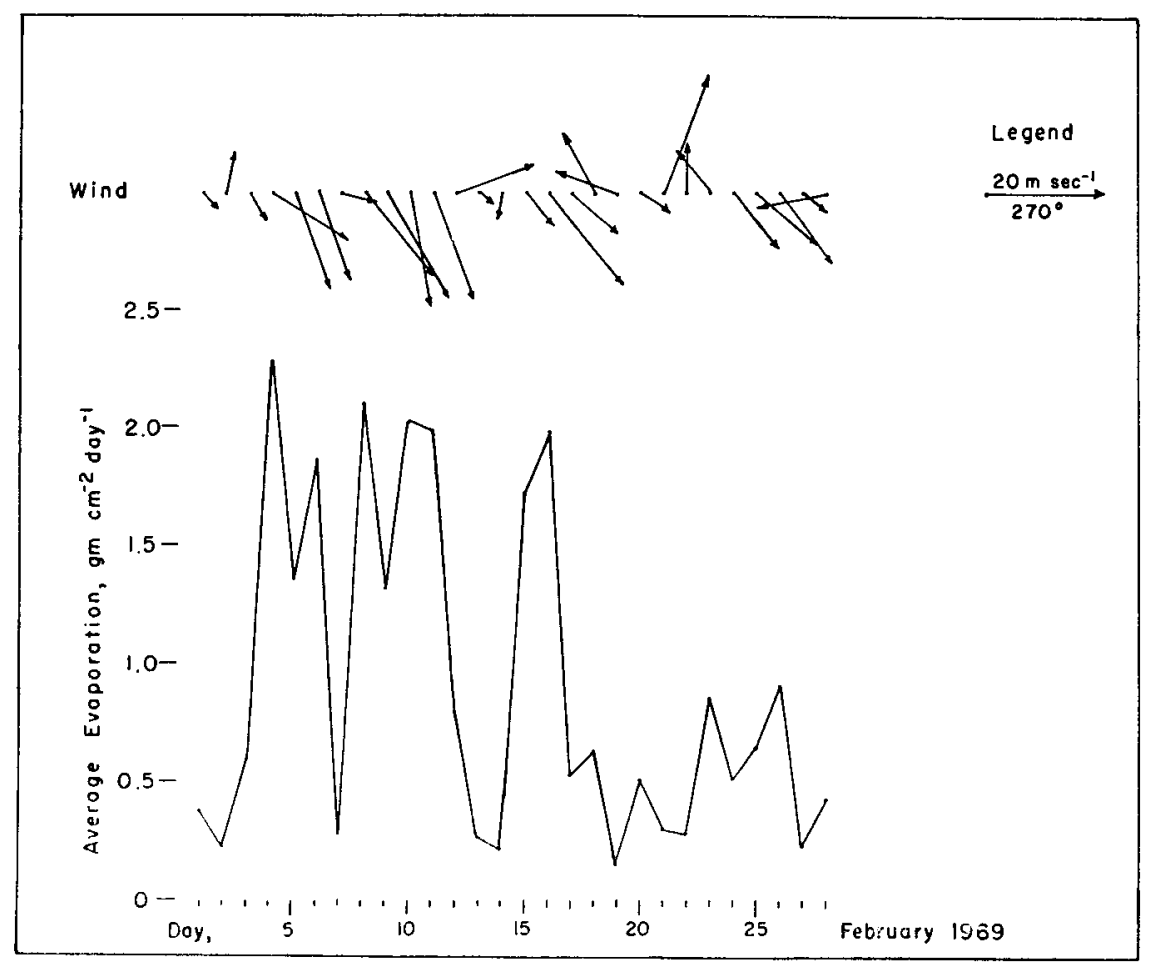

FIG. 7. Daily averages of evaporation and vector winds during February 1969 over the sea south of France to $40 \mathrm{~N}$.

monthly and daily means, respectively:

$$
\begin{aligned}
& E=(0.216)\left(0.98 q_{w}-q_{a}\right) W, \\
& E=(0.194)\left(0.98 q_{w}-q_{a}\right) W .
\end{aligned}
$$

Data entered into these equations were obtained from the SSMO, the Bouée Laboratoire, R/V Jean Charcot, $\mathrm{R} / \mathrm{V}$ Atlantis $I I$, and merchant ships.

Observations were taken at BL six times per day throughout the month of February. The average evaporation for the entire month found from these observations was $0.88 \mathrm{gm} \mathrm{cm}^{-2} \mathrm{day}^{-1}$. The averages for the 12 mistral days was $1.51 \mathrm{gm} \mathrm{cm}^{-2}$ day $^{-1}$, while the average for the remaining days was $0.41 \mathrm{gm} \mathrm{cm}^{-2} \mathrm{day}^{-1}$. The highest evaporation occurred on 9 February when 2.30 $\mathrm{gm} \mathrm{cm}^{-2}$ day $^{-1}$ evaporated from the surface. The lowest evaporation $0.09 \mathrm{gm} \mathrm{cm}^{-2} \mathrm{day}^{-1}$, occurred on 20 February when the winds were light and variable and the humidity was high. These values together with the previously computed values have been listed in Table 5 for comparison.

In column 2 the prevailing wind pattern for each day is given. In the last column the daily average of all determinations is given. Overall averages for all types of observations are given in the 29th row. In the 30th row the averages of the $E$ values computed from Bouée Laboratoire observations for the same dates are given. The last row gives the percentage of the average for a type of measurement with respect to the buoy average. The evaporation value for 23 February (enclosed in parentheses) was determined along the trajectory from Palma to the R/V Jean Charcot.

The averages allow a comparison of the various methods of determining evaporation and the determination of the mean evaporation for the month of February 1969. The average of the daily values in the last column is $0.91 \mathrm{gm} \mathrm{cm}^{-2} \mathrm{day}^{-1}$.

It is seen that the turbulence flux and volume flux methods give a low average of $62 \%$ of the buoy average for the same dates; the formula method applied to ship observations gives an average of $85 \%$ of the buoy value; and the trajectory methods give high values of $168 \%$ of the buoy evaporation. It would be desirable to use the mean evaporation determined from the other methods as a check on the correctness of the constant, 0.194, used in the evaporation formula, but because of the wide spread in the values such a check would be unsound.

It cannot be stated which technique is the most reliable from a comparison of the tabulated values. The aircraft turbulent flux and volume fiux techniques probably are the two least reliable methods. The aircraft technique required a correction determined by comparing computations under different conditions of atmospheric stability and hence may be in error. The volume technique suffers from non-representative values of wind and humidity, possible non-steady-state conditions, and depends upon small differences between 
large quantities. The trajectory technique applied to the Nimes-Jean Charcot observations may be the most reliable since conditions are more likely to be approximately steady state over short times and distances, and the winds over the water are more representative. The greatest source of error may arise from subsidence of the air between the Alps and the Pyrenees with a consequent drying of the air aloft.

Accepting the trajectory and the formula techniques as the most reliable methods, the daily averages for February have been recomputed using only the results from these techniques. The February average evaporation from these daily averages is $0.97 \mathrm{gm} \mathrm{cm}^{-2}$ day ${ }^{-1}$, a value not significantly different from the average determined from all techniques.

The daily average evaporations from Table 5 and vector presentations of the daily winds have been plotted in Fig. 7. The large variation of the daily evaporation and its dependence upon both wind speed and direction are demonstrated.

\section{e. Climatological values of evaporation from the Mediter- ranean $\mathrm{Sea}$}

Tables 3, 15, 16 and 20 of SSMO give the monthly averages of the wind speed, air temperature, relative humidity and sea temperature for each of 33 areas within the Mediterranean basin. From these data mean monthly and annual evaporation rates have been determined by use of Eq. (8a). The annual evaporation rates show that evaporation maxima occur in the eastern Mediterranean, Gulf of Sidra, and south of the Rhone Valley. The average annual evaporation over the whole sea is $0.43 \mathrm{gm} \mathrm{cm}^{-2} \mathrm{day}^{-1}$, corresponding to $157 \mathrm{gm} \mathrm{cm}^{-2}$ year $^{-1}$. This value is $8 \%$ higher than the

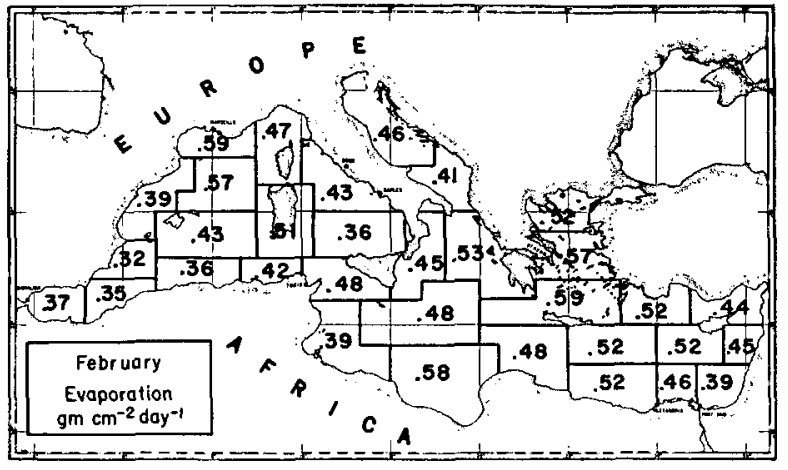

Frg. 8. February evaporation rates computed from Eq. (8) using averages in SSMO.

value determined by Sverdrup (1942) and Wüst (1952) based on the water budget of the Mediterranean Sea.

The mean evaporation for February is presented in Fig. 8. Here, again, maxima appear in the eastern Mediterranean, the Gulf of Sidra, and south of the Rhone Valley. The aveiage for Areas 7 and 8, in which the present study was carried out, is $36 \%$ less than the average found for February 1969. This difference arises from an unusual frequency of mistral winds during February 1969 which is discussed later.

Evaporation rates for the two areas south of the Rhone Valley have been computed for each month of the year from SSMO data. The results are presented in Fig. 9 together with the gain in sensible heat and latent heat by the atmosphere. As expected the evaporation is low during the summer months and reaches a maximum in December. The great loss of water vapor and heat from October through February is a

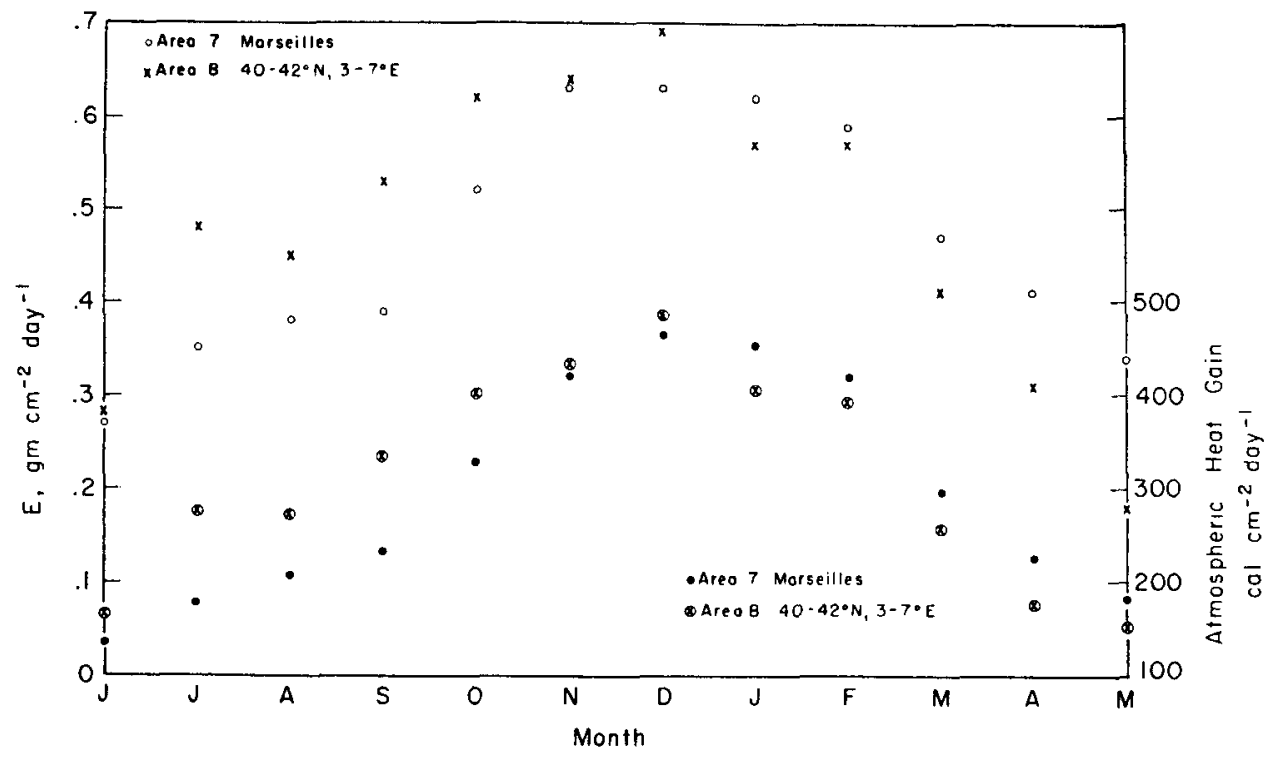

FIG. 9. Monthly values of the evaporation and heat gain by the atmosphere for the two areas south of France to 40 N. Eqs. (8) and (11) were used with data from SSMO. 
TABLE 6. Monthly mean marine heat exchange (cal cm${ }^{-2} \mathrm{day}^{-1}$ ), France to $40 \mathrm{~N} .{ }^{*}$

\begin{tabular}{|c|c|c|c|c|c|}
\hline Month & $L E$ & $S H F$ & $S R$ & $\begin{array}{l}I R_{a} \text { heat } \\
\text { exchange }\end{array}$ & $\begin{array}{l}\text { Net sensible } \\
\text { heat exchange }\end{array}$ \\
\hline January & $\begin{array}{l}-351(-225) \\
-342(-537)\end{array}$ & $\begin{array}{l}-72(-42) \\
-59(-230)\end{array}$ & $\begin{array}{l}170 \\
243\end{array}$ & $\begin{array}{r}-96 \\
-105\end{array}$ & $\begin{array}{l}-349(-193) \\
-263(-678)\end{array}$ \\
\hline $\begin{array}{l}\text { February } \\
\text { March }\end{array}$ & $\begin{array}{l}-342(-531) \\
-260(-295)\end{array}$ & $\begin{array}{l}-59(-230) \\
-14(-74)\end{array}$ & $\begin{array}{l}243(194) \\
340\end{array}$ & $\begin{array}{r}-105 \\
-97\end{array}$ & $\begin{array}{r}-203(-078) \\
-31(-126)\end{array}$ \\
\hline April & -212 & +14 & 480 & -107 & +175 \\
\hline May & -182 & 17 & 581 & -107 & +309 \\
\hline June & -161 & 14 & 609 & -117 & +345 \\
\hline July & -243 & 21 & 658 & -132 & +304 \\
\hline August & -242 & 9 & 564 & -107 & +224 \\
\hline September & -269 & -7 & 417 & -104 & 37 \\
\hline October & -334 & -24 & 280 & -97 & -175 \\
\hline November & -373 & -48 & 192 & -106 & -335 \\
\hline December & -389 & -79 & 150 & -125 & -443 \\
\hline Mistral days & -920 & -383 & 213 & -164 & -1254 \\
\hline
\end{tabular}

* Averages for 1969 in parentheses.

major factor conditioning the surface water so that it is dense enough to sink.

\section{Energy fluxes of the sea and air}

The monthly averages of the heat exchanges between the sea, the atmosphere, the sun and space for the area of the Mediterranean Sea from the coast of France to $40 \mathrm{~N}$ have been determined by summing the terms

$$
\begin{aligned}
& H_{\mathrm{sea}}=-L E-S H F+S R_{\mathrm{Abss}}+I R_{s} \downarrow-I R_{s} \uparrow, \\
& H_{\mathrm{air}}=L E+S H F+S R_{\mathrm{Al} \mathrm{sa}}+I R_{s} \uparrow-I R_{s} \downarrow-I R_{\imath} \uparrow .
\end{aligned}
$$

Here $L E$ is the evaporation times the latent heat of condensation of water vapor; $S H F$ is the sensible heat flux; $S R_{\mathrm{Abss}}$ and $S R_{\mathrm{Absa}}$ are the shortwave solar radiation amounts absorbed by the sea and by the atmosphere; $I R_{s \downarrow} \downarrow$ is the downward flux of infrared radiation at the sea surface; $I R_{s} \uparrow$ is the upward flux at the sea surface; and $I R_{\ell} \uparrow$ is the net upward flux at the $100-\mathrm{mb}$ level.

The flux of sensible heat has been found from Budyko's (1963) equation:

$$
\begin{array}{r}
S H F=c_{p} \rho C_{D}\left(T_{s}-T_{a}\right)(W)=0.52\left(T_{s}-T_{a}\right) W \\
{\left[\mathrm{cal} \mathrm{cm}^{-2} \mathrm{day}^{-1}\right],}
\end{array}
$$

where $T_{s}$ and $T_{a}$ are the sea and air temperatures $\left({ }^{\circ} \mathrm{C}\right), c_{p}$ the specific heat of air, and $W$ the wind speed $\left(\mathrm{cm} \mathrm{sec}^{-1}\right)$.

The amount of solar radiation absorbed by the sea has been determined from solar radiation values and albedos given by Budyko (1963) in conjunction with cloud amounts given in SSMO for the corresponding months over the Mediterranean. The amount of solar radiation absorbed by the atmosphere has been determined using London's (1957) percentages of absorption of radiation at $42 \mathrm{~N}$ at different seasons. Absorption by ozone was excluded since only the atmosphere below $100 \mathrm{mb}$ is being considered.

To obtain the infrared exchange of energy the Elsasser (1942) infrared diagrams were constructed using the monthly mean soundings for Nimes and Palma. Optical depth curves were plotted for clearand cloudy-sky conditions for each month. The mean infrared fluxes were found by weighting the clear-sky and cloudy-sky fluxes by mean cloudiness.

The mean heat exchanges for the sea and atmosphere are given in Tables 6 and 7. The monthly averages for January and March 1969 determined from BL data and the February 1969 averages of all measurement techniques were determined for comparisons with SSMO data. The absorption of solar radiation by the sea was found by averaging the daily radiation received aboard the $\mathrm{R} / \mathrm{V}$ Allantis $I I$ and applying an albedo of $9 \%$. In the tables these averages for 1969 are enclosed in parentheses.

Table 6 shows that the strong cooling of the Mediterranean sea water during the winter results from the large amount of heat loss by evaporation which the diminished solar radiation absorption cannot replace. Sensible heat exchange to the atmosphere and net infrared radiation loss contribute to the cooling but play minor roles.

During October through January a net loss of 40 $\mathrm{kcal} \mathrm{cm}^{-2}$ of heat and $60 \mathrm{~cm}$ of water occurs. If this loss is confined to the top $200 \mathrm{~m}$ of the sea, the temperature will decrease by about $2 \mathrm{C}$ and the salinity will increase by about 0.12 part per thousand. These changes will increase the density by $0.0005 \mathrm{gm} \mathrm{cm}^{-3}$. This increase is about the amount required to make water unstable and allows mixing of the warmer and saltier Levantine intermediate water to the surface. The further cooling of this mixed water during February makes the water dense enough to sink to the bottom.

The net annual heat loss found by averaging the monthly net heat exchange is $-17 \mathrm{cal} \mathrm{cm}^{-2}$ day-1. Sverdrup states that $1.75 \times 10^{12} \mathrm{~cm}^{3} \mathrm{sec}^{-1}$ of surface water flows into the Mediterranean Sea with a temperature of $14 \mathrm{C}$ while $1.68 \times 10^{12} \mathrm{~cm}^{3} \mathrm{sec}^{-1}$ flows out beneath the surface current with a temperature of $13 \mathrm{C}$. Thus, $2.66 \times 10^{12} \mathrm{cal} \mathrm{sec}^{-1}$ are lost within the basin corresponding to an average daily loss of $9.1 \mathrm{cal} \mathrm{cm}^{-2}$. Lacombe 
Tabie 7. Monthly mean atmospheric heat exchange (cal $\mathrm{cm}^{-2}$ day-1), France to $40 \mathrm{~N} .^{*}$

\begin{tabular}{|c|c|c|c|c|c|c|c|}
\hline Month & $L E$ & $S H F$ & $S R_{\mathrm{Abs}}$ & $\begin{array}{l}I R \text { heat } \\
\text { exchange }\end{array}$ & $\begin{array}{l}\text { Net radiational, } \\
\text { sensible and } \\
\text { latent heat } \\
\text { exchange }\end{array}$ & $L P$ & $\begin{array}{l}\text { Net radiational } \\
\text { and sensible heat } \\
\text { exchange }\end{array}$ \\
\hline January & $351(225)$ & $72(42)$ & 50 & -238 & $235(79)$ & 46 & $-70(-100)$ \\
\hline February & $342(537)$ & $59(230)$ & 69 & -236 & $234(600)$ & 45 & $-63(109)$ \\
\hline March & $260(295)$ & $14(74)$ & 72 & -280 & $66(161)$ & 46 & $-148(-88)$ \\
\hline April & 212 & -14 & 97 & -306 & -11 & 46 & -177 \\
\hline May & 182 & -17 & 112 & -325 & -48 & 36 & -194 \\
\hline June & 161 & -14 & 141 & -338 & -50 & 24 & -187 \\
\hline July & 243 & -21 & 140 & -350 & 12 & 10 & -221 \\
\hline August & 242 & -9 & 126 & -358 & 0 & 19 & -223 \\
\hline September & 269 & 7 & 98 & -340 & 34 & 49 & -186 \\
\hline October & 334 & 24 & 70 & -314 & 114 & 75 & -145 \\
\hline November & 373 & 48 & 50 & -290 & 181 & 79 & -113 \\
\hline December & 289 & 79 & 45 & -256 & 257 & 58 & -74 \\
\hline Mistral & 920 & 383 & 69 & -314 & 1058 & 24 & 162 \\
\hline
\end{tabular}

* Averages for 1969 in parentheses.

(1961) measured smaller velocities in the Strait of Gibraltar which give an average daily heat loss of 5.1 cal $\mathrm{cm}^{-2}$. This difference between the heat loss south of France determined from air-sea and radiational exchanges and the heat loss determined for the entire Mediterranean Sea from heat flow through the Strait of Gibraltar can be shown to result from a warming of the Atlantic water as it flows through the eastern Mediterranean Sea followed by cooling in the western basin. Temperature cross sections presented by Miller et al. (1970) show that the temperature increases as the water circulates through the eastem basin and cools as it flows back into the westem basin. As a check on the heating in the eastern basin, the annual air-sea and radiational heat exchanges in an area southwest of Cyprus between 33 and $35 \mathrm{~N}$ has been calculated from the SSMO data. The annual heat exchange of the water in this area was found to be $+43 \mathrm{cal} \mathrm{cm}^{-2} \mathrm{day}^{-1}$. Thus, the incoming Atlantic water gains heat, in spite of large evaporative losses, as it circulates through the eastern basin. As it moves westward it loses the heat accumulated in the eastem basin and cools to a temperature $1 \mathrm{C}$ less than the temperature it had as it entered the basin from the Atlantic Ocean about 80 years earlier.

In Table 7 the net exchanges of radiational, sensible and latent heats are listed in column 6 . These values show that the atmosphere has a net gain of energy during the winter but loses energy during the summer. The large losses by infrared radiation energy are more than compensated for by latent heat gained from evaporation during the winter but not in the summer.

In column 7 the averages of the heat released by the formation of rain $(L P)$ are given. The rainfall used was $48 \%$ of the monthly averages of seven stations surrounding the area. The net exchange of radiational and sensible heat by the troposphere was found by summing $L P$ with the other terms of heat exchange except the latent heat exchange ( $L E)$ and is entered in column 8 . Considering the sum of these terms it is seen that the atmosphere loses energy during every month of the year. The one exception occurred in February 1969 when the atmosphere gained sensible heat.

By comparing the heat exchange during three months of 1969 with the heat exchanges determined from long term climatological data it is seen that significant variations from the mean occur. In January 1969 the heat exchange was about half the normal value. In February and March 1969 the exchanges were more than twice the normal values. This variation is related to the number of occurrences of the mistral winds. In January the mistral wind blew on only 7 days while in February there were 12 occurrences. During the last part of March 1969 the mistral wind blew for eight consecutive days with velocities ranging from $20-40 \mathrm{kt}$.

The heat exchanges occurring during the 12 days of February 1969 with mistral winds have been averaged and entered in Tables 6 and 7 on the last row. The averages for the latent heat fluxes were formed from values determined by all techniques. The exchange of infrared radiation was found by using the radiosonde observations abtained by $\mathrm{R} / \mathrm{V}$ Jean Charcot on 9 February 1969 stationed at 42N, 5E. The rainfall was observed at the Bouée Laboratoire. The outstanding features of these averages are the large heat loss by the sea and the gain in sensible and latent heat by the atmosphere during the mistral regimes.

Acknowledgments. This paper could not have been written without the enthusiastic help of many people on both sides of the Atlantic. The author thanks them all. Thanks are also due to Mrs. Margaret Chaffee Cornell who acted as observer on the C-54Q aircraft, reduced much of the data, and drafted the figures for this paper. 


\section{REFERENCES}

Benton, G., and M. Estoque, 1954: Water vapor transfer over the North American continent. J. Meteor., 11, 462-477.

Budyko, M. I., 1963: Allas of the Heat Balance of the Earth. Moscow, Globnaia Geofiz., 69 charts. Also, Guide to the Allas of the Heat Balance of the Earth. Translated by I. A. Donehoo, Weather Bureau, WB/T-106, Washington, D. C.

Bunker, A. F., 1955: Turbulence and shearing stresses measured over the North Atlantic Ocean by an airplane acceleration technique. $J$. Meteor., 12, 445-455.

- 1960 : Heat and water vapor fluxes in air flowing southward over the western North Atlantic Ocean. J. Meteor., 17, $52-63$.

- - , and M. C. Cornell, 1971: Wintertime interactions of the atmosphere with the Mediterranean Sea. Woods Hole Oceanographic Institution, Ref. No. 71-61, 36 pp, 40 figs.

Elsasser, W. M., 1942: Heat transfer by infra-red in the atmosphere. Harvard Meleorological Studies, No. 6, Harvard University, Blue Hill Meteor. Observ., $107 \mathrm{pp}$.

Fleagle, R. G., F. I. Badgley and Y. Hsueh, 1967: Calculation of turbulent fluxes by integral methods. J. Atmos. Sci., 24, $356-373$.

Garstang, M., 1965: Sensible and latent heat exchange in low latitude synoptic-scale systems. Tech. Note 9-SAIL-1, ESSA, Washington, D. C., 105-146.

Haurwitz, B., and J. M. Austin, 1944: Climatology. New York, McGraw-Hill, $410 \mathrm{pp}$.

Jacobs, W. C., 1942: On the energy exchange between sea and atmosphere. J. Marine Res., 5, 37-66.

Kendrew, W. G., 1942: The Climates of the Continents. New York, Oxford University Press, $473 \mathrm{pp}$.

Lacombe, H., 1961 : Contribution a l'étude du régime du Detroit de Gibraltar. Cah. Oceanogr., 13, No. 2, 73-107.

Laevastu, T., 1965: Synoptic scale heat exchange and its relations to weather. Tech. Note 9-SAIL-1, ESSA, Washington, D. C., $257-283$.
London, J., 1957: A study of the atmospheric heat balance. New York University, AFCRC-TR-57-287, 99 pp. (AD117227).

McDonald, W. F., 1938: Atlas of the climatic charts of the oceans. Weather Bureau No. 1247, Washington, D. C., 130 charts.

MEDOC Group, 1970: Observations of formation of deep water in the Mediterranean Sea, 1969, Naure, 227, 1037-1040.

Meteorological Office, 1964: Weather in the Mediterranean, Vol. II. London, Her Majesty's Stationary Office, $372 \mathrm{pp}$.

Miller, A. R., P. Tchernia, H. Charnock and D. A. McGill, 1970: Mediterranean Sea Allas. Woods Hole Oceanographic Institution, Atlas Series, Vol. III, $190 \mathrm{pp}$.

Montgomery, R. B., 1940: Observations of vertical humidity distribution above the ocean surface and their relation to evaporation. Paper. Phys. Oceanogr. Meteor., 7, No. 4, 30 pp.

Panofsky, H., and R. A. McCormick, 1960: The spectrum of vertical velocity near the surface. Quart. J. Roy. Meteor. Soc., 86, 295-503.

Serra, A., 1958: Introduzione allo studio della climatologia dinamica della Sardgena. Riv. Meteor. Aeron., 18, No. 1, $1,3-27$.

Starr, V. P., and J. P. Peixoto, 1958: On the global balance of water vapor and the hydrology of deserts. Tellus, 10, 188-195.

Sverdrup, H. U., 1937: On the evaporation from oceans. J. Marine Res., 1, 3-14.

—, 1942: Oceanography for Meteorologists. New York, PrenticeHall, 235 pp.

U. S. Naval Weather Service Command, 1970: Summary of synoptic meteorological observations-Mediterranean marine areas. Nine volumes, National Technical Information Service, Springfield, Va.

Wu, J., 1969: Wind stress and surface roughness at the air-sea interface. J. Geophy. Res., 74, 444-455.

Wüst, G., 1952: Der Wasserhaushalt des Mittel-landischer Meeres und der Ostee in Vergleichender Betrachtung. Geof. Pura Appl., 21, 1-14.

- 1961 : On the vertical circulation of the Mediterranean Sea. J. Geophy. Res., 66, 3261-3271. 